\title{
DOES CORPORATE GOVERNANCE INFLUENCE FIRM VALUE IN BANGLADESH? A PANEL DATA ANALYSIS
}

\author{
Mohammed Nazim Uddin', Mosharrof Hosen ${ }^{2}$, Mustafa Manir \\ Chowdhury ${ }^{3}$, Tanbina Tabassum ${ }^{4}$, Manjurul Alam Mazumder ${ }^{5}$
}

\footnotetext{
1 International Islamic University Chittagong, Faculty of Business Studies, Department of Business Administration, Bangladesh, nazim_bgc@yahoo.com;

2 Universiti Tunku Abdul Rahman, Faculty of Business and Finance, Department of Business Administration, Malaysia, ORCID: 0000-0002-9301-4318, jonycox74@gmail.com (corresponding author);

3 International Islamic University Chittagong, Faculty of Business Studies, Department of Business Administration, Bangladesh, mustafa_manir@iiuc.ac.bd;

4 Premier University, Faculty of Business Studies, Department of Finance, Bangladesh, tanbinatabassum@yahoo.com;

5 International Islamic University Chittagong, Faculty of Business Studies, Department of Business Administration, Bangladesh, manjurulm4@gmail.com.
}

\begin{abstract}
Corporate governance has been widely debated for over a decade with the collapse of the financial and capital market under the prejudicial roles of regulatory bodies. Therefore, the study examined the impact of corporate governance on firm value in Bangladesh. A total of 63 DSElisted companies from 2005 to 2019 consisting of 8,505 observations on an average of 15 years were chosen. The subsequent tests for the given data were conducted to identify the appropriate panel data analysis method for adjusted diagnostic problems. In the specific panel data, the Panel Corrected Standard Error (PCSE) was utilised following the application of the random effects method to control econometric limitations. It was revealed that corporate governance lowered firm value when the board structure was familially and politically affiliated and led by CEO-duality. Moreover, the inclusion of dynamic professionals and independent members in the board structure increased the firm value. The use of the corporate governance code was proven to be highly challenging due to the participation of political and family leaders in corporate firms. Additionally, proper law enforcement was required to ensure transparency and accountability, thus reflecting firm value. As previous studies on corporate governance were conducted on a small scale and partial to the context of developing countries, this paper contributes a novel value in identifying and resolving the corporate governance crisis by reforming the board structure with diverse and professional directors. The regulatory bodies require improvement by including autonomous professional and independent members to exercise the corporate governance code.
\end{abstract}

Keywords: Board size, board independence, CEO-duality, corporate governance, firm value, Bangladesh.

JEL Classification: C51, L11.

APA Style Citation: Uddin, M. N., Hosen, M., Chowdhury, M. M., Tabassum, T., \& Mazumder, M. A. (2021). Does Corporate Governance Influence Firm Value in Bangladesh? A Panel Data Analysis. E\&M Economics and Management, 24(2), 84-100. https://doi.org/10.15240/ tul/001/2021-2-006

\section{Introduction}

Corporate governance has been a critical issue focused by regulatory bodies, policymakers, and academicians to improve the economic and sustainability conditions in developing countries for over a decade (Brown et al., 2011; Wintoki et al., 2012; Claessens, 2006). Additionally, the collapse of corporate 
governance has compromised the government legally, financially, and economically, resulting in a lack of accountability in Bangladesh. An organised financial system includes proper asset allocation, fund abuse prevention, minority interest protection, and timely dividend payment to improve the corporate governance system and enable corporate laws to enhance firm value (La Porta, 2006). In a competitive global market, a robust regulatory framework is required to mandate organisational compliance involving policies and procedures to ensure accountability (Uddin et al., 2019). In corporate governance practices, firms could ensure proper resource distributions among various stockholders to efficiently deliver supplies and managerial functions in competing against global market shares (Uddin et al., 2019). Consequently, corporate governance practices increased the investors' confidence in stock market stability by committing to financial and management services, such as regular AGM, dividends, information, and accountabilities through sound financial policies. The absence of sound financial policies would prevent firms from gaining the faith of suppliers, lenders, governmental and regulatory bodies, employees, and investors and may eventually collapse.

Given the severe corporate governance issues in Bangladesh, the government and public were unethically motivated to implement unauthorised frameworks for personal gains. The subsequent conflict between the government and the people led to the powerwielding of the current government through an army-backed government conspiracy in 2009. The previous (army-backed) government wrested power from the acting government through the pressure of arms and ruled Bangladesh from 2006 to 2008. Although Bangladesh was established as a democratic country in 1971, the country was seldom ruled by a democratic government. The power struggle among political parties resulted in corruption, unethical profit-making, and the use of power that led to the collapse of the capital market (Uddin et al., 2019). Regarding political connections, firms and institutions were owned and managed by a few persons, families, or institutions, thus defying corporate governance rules and regulations which controlled the global impact of corporate sectors. As such, the current governance issue raised two questions: (i) how a flawed corporate governance system could impact the economy and firm value and (ii) how the current corporate governance system could improve firm value. In response to both questions, the paper examines the corporate governance impact on firm value in Bangladesh.

Corporate governance connects good management and firm value by allowing ownership separation and conflict management to lessen agency issues (Céspedes et al., 2010; dos Santos Silva et al., 2011). Hence, the board could play an intermediary role between the management team and shareholders with responsibilities involving supervision, replacing executives with poor performance, adapting sound financial policies, and ensuring accountabilities. With the coordination of functional responsibilities and delegation of board duties, managers would improve and enhance the value of the corporate governance status. Weekes-Marshall (2014) argued that managers undertaking corporate affairs with honesty, sincerity, efficiency, and transparency increased the faith of stakeholders and enhanced firm value. On the contrary, a board and financial managers with no active compliance to corporate governance ethics may result in the collapse of firm value.

Although several studies examined corporate governance through cross-sectional country analyses in developed economies, corporate governance emerged as a pandemic in developing countries such as Bangladesh. For example, Mitton (2002) conducted a study on five Asian countries to show the specific effects of corporate governance on financial performance and significantly contributed to corporate financial performance. Additionally, Haque et al. (2011) reviewed the initial effort on corporate governance using primary data which obscured the main influential variables, such as board size, board composition, institutional shareholdings, and managerial ownership. As previous cross-sectional study analyses in developed countries failed to capture the individual analysis of developing countries, the gap identification proved advantageous in analysing and comparing among individual, cross-country, developed, and undeveloped countries regarding the corporate governance impact on firm value. For example, Joh (2003) examined the effect of corporate governance on Korean firms and found a decline in financial 
performance. Therefore, a cross-sectional analysis may not be appropriate for individual policy implications.

This paper includes 63 DSE-listed manufacturing companies in Bangladesh for the following reasons: (i) The listed companies led the economy and supplied all the systematic data related to corporate governance in the annual reports from 2005 to 2019; (ii) Manufacturing companies were the mainstream of economic growth, production, and employment creation. The manufacturing sector played a significant role in providing basic public needs and economic sustenance; (iii) A significant number of investors invested capital in the companies. The influence of corporate performance on investment would impact the Bangladeshi stock market that has collapsed in recent times with the decline in corporate governance (WeekesMarshall, 2014); (iv) An impetus for conducting the study on manufacturing companies to provide more significant job opportunities for unemployed Bangladeshis.

Hence, the main contributions of the paper include: (i) A new test result involving corporate governance impact on firm value in developing countries such as Bangladesh, as opposed to the cross-country analyses in developed countries in previous studies. Provided that no suitable estimation method for data analysis was applied In Bangladesh or other developing countries (Wintoki et al., 2012), a proper estimation technique was performed to adjust the diagnostic issues of the data set. Regarding the data set type, Torres-Reyna (2007) and Beck and Katz (1995) utilised PSCE for the data inclusion of serial correlations, heteroskedasticity, and cross-sectional problems as the conclusion. (ii) The previous studies on corporate governance and firm value in Bangladesh were inconsequential, partial, and grounded on primary data within limited scope and methods (Haque et al., 2011); (iii) A new estimation factor concerning the impact of corporate governance on firm value was considered to highlight the ownership nature of Bangladeshi families and political leaders due to the severity and uncontrollability of the corporate governance issue. Therefore, this paper presents new and imperative evidence regarding corporate governance impact on firm value in Bangladesh.

The paper is structured as follows: Section 1 describes the relevant literature and hypotheses development; Section 2 elaborates on theory, variable definitions, data collection, and methodology; Section 3 ascertains the findings and analysis of results in the Bangladesh context. Finally, the paper draws to a conclusion with policy implications.

\section{Relevant Literatures and Hypotheses}

\subsection{Determinants of Corporate Governance and the Impact on Firm Value, Research Hypotheses}

\section{Board Size and Firm Value}

Board size is defined as the length of the board structure linked to firm value. Larger board structure increases the complexity in decisionmaking. Although no link was identified between the board structure and firm value in several studies on listed corporate firms using OLS (Rouf, 2011; Rashid et al., 2010), Gill et al. (2011) reported a negative link between corporate governance and firm value in examining listed Canadian firms. Additionally, Carter et al. (2003) revealed a positive and significant impact of corporate governance on firm value.

Pucheta-Martínez (2015) argued that most of the previous studies accepted the agency theory to explain the relationship between corporate governance and firm value creation. Nevertheless, a mixed approach could be adapted to describe the link between corporate governance and firm value following the stewardship theory. Hence, the following hypothesis is developed from the theoretical background: value.

$H_{1}$ : Board size can negatively influence firm

\section{Board Composition and Firm Value}

The agency theory argues that the consideration of external directors in board composition would reduce agency issues through a strong monitoring role (Cheng, 2008). External executives are typically efficient individuals from other organisations with the expertise to control the current organisation. The appointment of external executives to the board positively influenced corporate governance and firm value (Nguyen \& Faff, 2007; KyereboahColeman \& Biekpe, 2006).

Several previous studies examined the link between board composition and firm 
value (Hermalin \& Weisbach, 1991). For example, Combs et al. (2007) found an inverse relationship between board composition and the stock market that may not benefit shareholders. Nonetheless, some studies indicated the absence of a link between board composition and firm value (Hermalin \& Weisbach, 1991; Bhagat \& Black, 2001). Based on the theoretical and empirical discussions, the following hypothesis is developed:

$\mathrm{H}_{2}$ : Board composition positively leads to firm value.

\section{Managerial Ownership and Firm Value Link}

The agency theory predicts that diverse managerial ownership acts results in improved shareholder interest. The dual owner-manager role would involve more functional activities to control the firm in creating shareholder values. Kumar and Singh (2013) estimated that the positive link between ownership and firm value changed through managers and firm value or performance. Additionally, Lee et al. (2008) estimated that managers worked more to enhance firm value by forming managerial ownership.

Acharya and Bisin (2009) also demonstrated that managerial ownership provided more incentive for managers to positively change firm value. The result concluded that managerial shareholdings on the board had a decisive role in firm value. Thus, the option of purchasing shares in firms would mitigate the agency problem and aid in maximising firm value (Kumar \& Singh, 2012). The following hypothesis is developed based on the theoretical ground:

$\mathrm{H}_{3}$ : Managerial ownership leads to enhanced firm value.

\section{Institutional Ownership and Firm Value}

The agency cost theory predicts that the conflict between shareholders and managers reduces firm value. Additionally, strong corporate governance could reduce agency cost through technical management between shareholders and managers. For example, Wei et al.'s (2005) study on the relationship between institutional ownership and firm value in 5,284 Chinese companies indicated an inverse relationship between institutional ownership and firm value.

In contrast, Navissi and Naiker (2006) who evaluated the relationship between institutional shareholdings and firm value in 123 companies found no impact of institutional shareholdings on firm value. The effect of institutional ownership on firm value depended on the nature of institutions, such as banks or investment companies and organisational control (Ruiz-Mallorquí \& Santana-Martín, 2011). The following hypothesis is developed from the previous discussion:

$H_{4}: A$ contrary relationship exists between institutional ownership and firm value.

\section{Board Independence and Firm Value}

McCabe and Nowak (2008) examined the impact of independent directors on the board in Australian listed companies by interviewing 30 directors. It was agreed that the participation of independent directors induced a balance of power and defended companies from partial decisions. Following the corporate governance code in Malaysian firms, $33 \%$ of independent directors are required on the board. Nevertheless, the internal control of firms failed to be monitored (Wooi \& Ming, 2009). In American companies, a significant percentage of directors on the board were independent directors who monitored and controlled the firms.

An inverse relationship between independent directors and the firm value was identified (Bhagat \& Black, 2001). Besides, Kumar and Sivaramakrishnan (2008) reported that independent directors on the board would intervene in managerial functions and cause more adverse outcomes. Lefort and Urzúa (2008) evaluated panel data in 160 companies to measure the relationship between board independence and firm value and reported a positively significant relationship between board independence and firm value. The increased participation of independent directors on board meetings reduced agency conflicts, thus leading to the following hypothesis:

$H_{5}$ : Board independence is positively related to firm value.

\section{CEO Duality and Firm Value}

Based on the agency theory, the board should be distinguished from the management to control and monitor managerial functions. A dually responsible leader may gain dictatorship that may negatively influence firm value. Despite the negative attitudes to firm performance, several management theories argued that joint leadership provided a significantly positive relationship between CEO duality and firm value. In Baliga et al. (1996), the correlation 
between CEO duality and firm performance indicated a significant relationship between CEO duality and company performance.

Yan Lam and Kam Lee (2008) investigated a study on 128 listed companies in Hong Kong to identify the relationship between CEO duality and accounting performance. The result revealed that dual leaders performed better in non-family oriented firms than family-based firms. In contrast, Boyd (1995) indicated no significant link between CEO duality and firm value. Peng et al. (2007) examined the impact of CEO duality on the financial analysis of 403 listed Chinese firms and found a significant connection between CEO duality and company performance in China. Hence, the following hypothesis is developed: value.

$H_{6}$ : CEO duality negatively influences firm

\section{Firm Size and Firm Value}

Firm size may involve exploring the financial benefits of a larger firm with a wide acquisition scope to derive financial services and vice versa. Regarding firm size, Cheng et al. (2010) revealed an inverse relationship between firm size and firm value, whereas Rajan and Zingales (1995) indicated a positive relationship between firm size and firm value in disclosing symmetrical information for more diversified products and services. Additionally, Titman and Wessels (1988) found that a more significant firm created a higher confidence level and lesser bankruptcy, thus increasing the market share demands. As such, the following hypothesis is developed:

$H_{7}$ : There is a positive relationship between firm size and firm value.

\section{Profitability and Firm Value}

Following the trade-off theory arguing that more profitable firms would create more firm value, Myers (2001) anticipated a positive correlation between profitability and firm value. The tradeoff theory demonstrated the inverted relationship between leverage use and firm value, whereas the pecking order theory suggested that firms focused on internal sources to use external financing, consequently resulting in a positive link between corporate profitability and firm value (Myers \& Majluf, 1984). As such, the following hypothesis is developed:

$H_{8}$ : Profitability positively influences firm value.
Previous literature indicated mixed and vague results that may be irrelevant to developing countries due to the examination of cross-country and developed country analyses rather than individual or developing countries. Hence, an individual country analysis is needed for policy implications in providing specific characteristics to be adapted in developing countries. To date, the relevant studies are confined to the few and partial study scopes, methods, and results. Although developing countries raised primary concerns of corporate governance issues involving corruption, lack of democracy, illiteracy rates, and poverty, most of the studies were conducted in developed countries. In light of the indicated study gaps, this study investigates the influence of corporate governance on firm value in Bangladesh.

\section{Theoretical Framework, Variables Definition, and Model Specification}

\subsection{Theoretical Framework That Explains the Link between Corporate Governance and Firm Value}

A theoretical framework was established to demonstrate how corporate governance impacted firm value. Musa et al. (2019) revealed that the corporate governance index positively marked the debt policy. In this vein, an increase in corporate governance attributes would enhance the debt level to maximise firm value. Corporate governance disclosure may have positive, negative, or no influence to firm value. A board size or board structure involved the number of member types on the board to monitor or control internal functions. Thus, board size was expected to negatively influence the firm value as a large board size led to complexity in decision-making, thus resulting in high management cost.

Board composition also influenced the proportion of external executives to the total number of directors classified as functional and non-functional directors. External executives were considered efficient individuals or experts from other organizations that positively contributed an outstanding performance to the board. A significant ratio of external directors was anticipated to positively influence firm value. In avoiding the unethical issues of the corporate world, the corporate governance code mandated the appointment of a percentage of total 
members on the board to facilitate board independence and demonstrate operational transparency and accountability. Therefore, a positive link is assumed between board independence and firm value. Furthermore, institutional shareholders comprised of block shareholders who dominated the board meeting and influenced firm value. Based on joint leadership, CEO duality positively or negatively impacted firm value and could reduce the conflict between managers and shareholders as an intermediary agent. The relationship was also affirmed by the agency theory regarding the conflicting interests between owners or principles and managers or agents (Robert, 2005). The following figure shows how independent variables determine firm value.

\subsection{Model Specification and Variables Measurement}

The econometrics model for measuring the relationship between corporate governance instruments and the firm value was developed by Rashid and Islam (2013) as shown below:

$$
\begin{aligned}
\mathrm{MBV}=B_{0} & +B_{1} B S+B_{2} B C+B_{3} I O+ \\
+B_{4} M N O & +B_{5} B I+B_{6} F S+B_{7} R O A+ \\
& +B_{8} \text { Duality }+e
\end{aligned}
$$

\subsection{Data Collection Strategy and Methodology}

A total of 63 DSE-listed companies were chosen from 2005 to 2019 consisting of 8,505 observations on an average of 15 years. The data obtained from the financial disclosures of the 63 companies included financial statements, cash flow statements, financial statement notes, and share market prices from the historical data cell record of DSE in Bangladesh. The samples were chosen from all the listed companies based on uninterrupted disclosures and subsequent market share tradings during the studied period. Besides, the study period ranged between 2005 and 2019 based on the uninterrupted data of the

\section{Fig. 1: Relationship between independent variables and firm value}

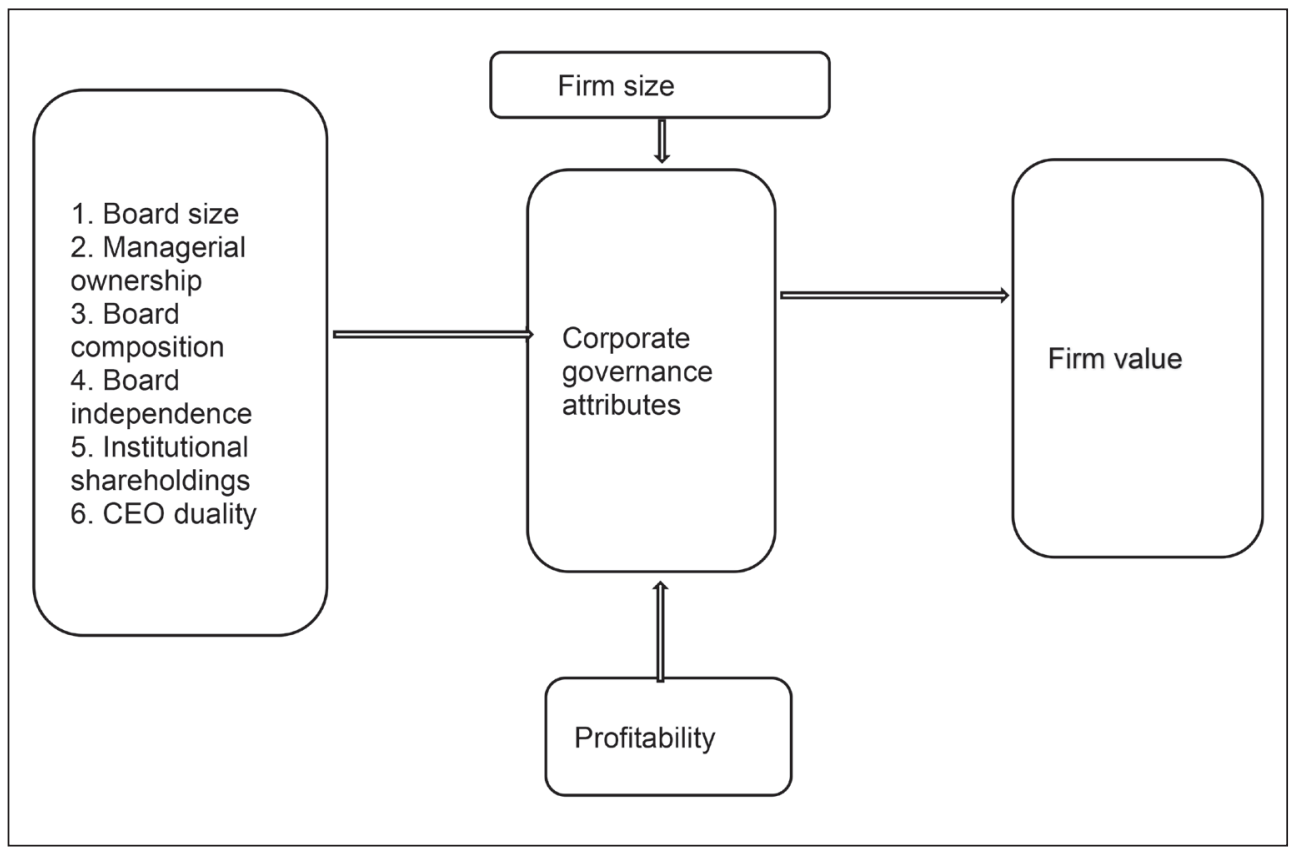


Tab. 1: Variables measurement and empirical studies

\begin{tabular}{|c|c|c|c|c|}
\hline & Variables & Description & $\begin{array}{l}\text { Measurement } \\
\text { of variables }\end{array}$ & Empirical studies \\
\hline $\begin{array}{l}\text { Dependent } \\
\text { variable }\end{array}$ & M/B & $\begin{array}{l}\text { Market to book } \\
\text { value }\end{array}$ & Market value/Book value & $\begin{array}{l}\text { Adeyemi et al., 2011; } \\
\text { Fumani \& Moghadam, } \\
\text { 2015; Alfiet al., } 2016\end{array}$ \\
\hline \multirow[t]{8}{*}{$\begin{array}{l}\text { Independent } \\
\text { variables }\end{array}$} & BS & Board size & Number of total directors & $\begin{array}{l}\text { Bhagat \& Black, 2001; } \\
\text { Abor \& Biekpe, } 2007\end{array}$ \\
\hline & $\mathrm{BC}$ & $\begin{array}{l}\text { Board } \\
\text { composition }\end{array}$ & $\begin{array}{l}\text { Non-executive directors/ } \\
\text { Total directors }\end{array}$ & Adegbile, 2015 \\
\hline & MNO & $\begin{array}{l}\text { Managerial } \\
\text { ownership }\end{array}$ & $\begin{array}{l}\text { Managerial shareholdings/ } \\
\text { Total shares }\end{array}$ & $\begin{array}{l}\text { La Porta et al., 2006; } \\
\text { Baek et al., 2004; } \\
\text { Gill et al., } 2009\end{array}$ \\
\hline & 10 & $\begin{array}{l}\text { Institutional } \\
\text { owners }\end{array}$ & $\begin{array}{l}\text { Institutional shares/Total } \\
\text { shares }\end{array}$ & Xu \& Wang, 1999 \\
\hline & $\mathrm{BI}$ & $\begin{array}{l}\text { Board } \\
\text { independence }\end{array}$ & $\begin{array}{l}\text { Independent directors/ } \\
\text { Total directors }\end{array}$ & $\begin{array}{l}\text { Erickson \& Wang, 1999; } \\
\text { Lefort \& Urzúa, 2008; } \\
\text { Duchin et al., } 2010\end{array}$ \\
\hline & FS & $\begin{array}{l}\text { Firm (size, control } \\
\text { variable) }\end{array}$ & $\begin{array}{l}\text { Firm size (natural } \\
\text { logarithm of total assets) }\end{array}$ & Titman \& Wessels, 1988 \\
\hline & ROA & $\begin{array}{l}\text { Return on asset } \\
\text { (control variable) }\end{array}$ & Net profit/Total assets & $\begin{array}{l}\text { Alagathurai, 2013; } \\
\text { Ehikioya, } 2009\end{array}$ \\
\hline & DUALITY & CEO/Chair & $\begin{array}{l}\text { CEO duality (a dummy } \\
\text { variable: takes } 1 \text { if both } \\
\text { are the same person } \\
\text { or } 0 \text { otherwise) }\end{array}$ & $\begin{array}{l}\text { Fosberg, 2004; } \\
\text { Abor \& Biekpe, } 2007\end{array}$ \\
\hline
\end{tabular}

chosen companies. Companies that began operating after 2005 were excluded from this study. The financial sector for different typical assets, functions, regulatory requirements, and capital rules involving manufacturing was also excluded (Diamond \& Rajan, 2000). In the econometric model, the firm value was followed by Tobin's $Q$ ratio as a good proxy in measuring firm value.

Corporate governance variables, such as board size, board composition, managerial ownership, board independence, and CEO duality were used to estimate corporate governance and control variables (firm size and profitability). All the variables were computed from various components of financial disclosures regarding sample firms from 2005 to 2019. Other necessary information was obtained from the Bureau of Statistics and the Bangladesh Bank website. The collected data covered the 12 economic sectors in
Bangladesh, namely, Cement, Ceramic, Engineering, Food and Allied, Fuel and Power, Information Technology, Jute and Textile, Paper and Printing, Pharmaceuticals and Chemicals, Service and Real Estate, Tannery and Footwear, and Miscellaneous industries.

\subsection{Methodology}

The panel estimation to control the heteroscedasticity and serial correlation problems invariantly continued over time. The subsequent panel data strategies were applied to develop the research purpose in terms of the panel ordinary least square, fixed effects, and random effects method. For example, Hausman (1978) indicated the random effect model as a suitable data analysis method. The data set managed possible serial correlation issues, heteroskedasticity, and cross-sectional problems. In the specific panel data, Beck and 
Katz (1995) allowed for the utilisation of PCSE to control the econometric limitations. Renowned researchers accepted the appropriateness and use of PCSE for panel data analysis through more than 2,000 citations worldwide in the Web of Science (Reed, 2017). Some pre-requisite tests were also performed before implementing the PCSE as described below:

Hausman (1978) test was introduced to discriminate between fixed effects and random effects in assessing the panel data set. Considering the study results, the random effects could be utilised in this study (Chisquared $>p$-value $=0.4623$ ).

Serial correlation test was presumed that no serial correlation issue was found in the given panel data set. The tested results indicated Prob. $>$ chi2 $=0.000$ based on the serial correlation test performed. The null hypothesis was rejected due to the existence of the serial correlation issue, regardless of whether the residuals were serially correlated across time.

Heteroskedasticity test: Heteroskedasticity is a common phenomenon in panel data analysis with variance in error terms across observations. Although no heteroskedasticity in error terms was found, the results indicated Prob. $>$ chi $2=0.000$. Hence, heteroskedasticity was reported in the data set.

Cross-sectional test was used to examine the absolute values of the cross-sectional correlations averaged on all the possible cross- sectional pair units (Robertson \& Symons, $2000)$. Although it was assumed that no crosssectional issues existed in the data set, the p-value of 0.000 indicated a cross-sectional issue.

\section{Empirical Results and Description}

The section examines the impact of corporate governance on firm value in Bangladesh from 2005 to 2019. The consequential test of statistics was employed and described following the corporate finance theory and corporate governance code in Bangladesh as given below.

Tab. 2 presents the descriptive statistics of corporate governance variables and the dependent variable. The dependent variable mean value was 3.41 , thus indicating that the firm value for sample companies was generally more significant than the book. Hence, companies were creating value for shareholders during the 15 years. The average board size was 7.39 (the minimum is five but not exceeding 20), neither big nor small, and was generally more useful for the managerial decisions adapted by the corporate governance code. The mean value of the non-executive director was $47.2 \%$ and indicated a high percentage to control internal functions by external executives. It was found that the average shares held by organisations were a high $24.3 \%$.

The mean of managerial shares was $33.1 \%$, thus revealing that managers were

\section{Tab. 2: Descriptive statistics result}

\begin{tabular}{l|c|c|c|c}
\multicolumn{1}{c|}{ Variable } & Min. & Max. & Mean & SD \\
\hline FV & 0.0219 & 62.19 & 3.413 & 5.914 \\
\hline BS & 3.000 & 15.00 & 7.39 & 2.092 \\
\hline BC & 0.000 & 0.909 & 0.472 & 0.251 \\
\hline IO & 0.000 & 0.2831 & 0.243 & 0.219 \\
\hline MNO & 0.000 & 1.000 & 0.331 & 0.224 \\
\hline BI & 0.000 & 0.600 & 0.094 & 0.104 \\
\hline FS & 9.634 & 24.284 & 20.066 & 2.159 \\
\hline ROA & -0.410 & 0.479 & 0.0518 & 0.056 \\
\hline Duality & 0 & 1.00 & 0.271 & 0.445 \\
\hline
\end{tabular}




\section{Business Administration and Management}

motivated to control organisations for shareholders' interests. The mean participation of independent directors was a low 0.09 compared to corporate governance (at least $10 \%$ ). The average firm size was a satisfactory 20.06 , whereas profitability was a low $5.18 \%$. The average value of CEO duality was 0.27 , hence demonstrating that $27 \%$ of the firms maintained CEO duality.

Tab. 3 presents the Pearson correlation coefficient to test the multicollinearity issues in the data set. Board size led to a positive and significant relationship with firm value, whereas a negative and significant relationship was indicated between board composition and firm value with a coefficient of -0.108 . Regarding managerial ownership, a negative and significant relationship between managerial ownership and firm value indicated that higher managerial ownership resulted in lower firm value. Additionally, board independence showed a significant negative relationship to firm value, hence revealing that higher participation of independent directors in board meetings reduced firm value. Therefore, firm size negatively influenced firm value. In the case of profitability, a significant and negative correlation between ROA and firm value was reported. Similarly, CEO duality negatively related to firm value with the coefficient of $-0.119$
In the multicollinearity issues, the VIF estimator indicated the range of value from 5 to 10 (Gill et al., 2010). As the calculated R-square values were considered lesser than the given range, no multicollinearity issues were identified in the data analysis.

Tab. 4 reports the multiple regression analysis results using the random effects model. Board size was positively and significantly related to firm value. In this vein, a bigger board size positively influenced firm value and vice versa. Therefore, the research hypothesis on the negative connection between board size and firm value was rejected. It was also indicated that the relationship between board composition and firm value was negative and significant, thus revealing that a greater percentage of external directors on the board reduced firm value. Following the pecking order theory, firms that pooled internal and external funds led to fewer agency conflicts in enhancing firm value (Mayers, 1984). Additionally, Wen et al. (2002) reported that a high rate of non-executive directors on the board reduced firm value. Hence, the research hypothesis on the link between board composition and firm value was rejected.

Concerning board independence, a significant role was detected between board independence and firm value. The positive relationship indicated that participating independent directors would enhance firm value. Independent directors provided an active role on the board to make accurate decisions

Tab. 3: Report of Pearson correlation matrix of variables

\begin{tabular}{l|c|c|c|c|c|c|c|c|c} 
& FV & BS & BC & IO & MNO & BI & FS & ROA & Duality \\
\hline FV & 1.000 & & & & & & & & \\
\hline BS & $0.106^{* *}$ & 1.000 & & & & & & & \\
\hline BC & $-0.108^{* *}$ & $0.231^{* *}$ & 1.000 & & & & & & \\
\hline IO & -0.007 & $0.066^{*}$ & $0.074^{*}$ & 1.000 & & & & & \\
\hline MNO & $-0.092^{*}$ & -0.006 & 0.014 & $-0.288^{* *}$ & 1.000 & & & & \\
\hline BI & $0.084^{* *}$ & -0.005 & $-0.531^{* *}$ & $-0.161^{* *}$ & -0.013 & 1.000 & & & \\
\hline FS & $-0.274^{* *}$ & -0.014 & -0.019 & $-0.096^{* *}$ & $0.228^{* *}$ & $0.217^{* *}$ & 1.000 & & \\
\hline ROA & $-0.389^{* *}$ & $0.236^{* *}$ & -0.020 & 0.029 & $-0.124^{* *}$ & 0.002 & $-0.116^{* *}$ & 1.000 & \\
\hline Duality & $-0.119^{* *}$ & $-0.202^{* *}$ & $0.182^{* *}$ & 0.047 & 0.029 & $-0.184^{* *}$ & -0.046 & $-0.186^{* *}$ & 1.000 \\
\hline
\end{tabular}




\begin{tabular}{l|c|c|c|c}
\multirow{2}{*}{ Variable } & \multicolumn{4}{c}{ Random effects model } \\
\cline { 2 - 5 } & Coefficient & Std. error & T-statistic & P-value \\
\hline Constant & 8.661655 & 3.406669 & 2.542559 & 0.0112 \\
\hline BS & $0.214043^{* *}$ & 0.104934 & 2.039780 & 0.0417 \\
\hline BC & $-1.454648^{*}$ & 0.798014 & 1.454648 & 0.0686 \\
\hline BI & $7.117421^{* *}$ & 1.783990 & 3.989608 & 0.0001 \\
\hline IO & -0.982449 & 0.972572 & 1.010155 & 0.3127 \\
\hline MNO & 1.773337 & 1.249924 & 1.418756 & 0.1563 \\
\hline FS & $-0.438903^{* *}$ & 0.162781 & 2.696281 & 0.0071 \\
\hline ROA & $33.03788^{* *}$ & 2.940975 & 11.23365 & 0.0000 \\
\hline Duality & -0.247102 & 0.408537 & 0.604846 & 0.5454 \\
\hline R-squared & & & 0.176402 & \\
\hline Adjusted R-squared & & & 0.169363 & \\
\hline S. e. of regression & & 3.678115 & \\
\hline F-statistic & & 25.05959 & 0.00000 \\
\hline Prob(F-statistic) & & & \\
\hline
\end{tabular}

for intense supervision and monitoring to properly sustain the firm. Based on the trade-off theory, well-governed firms had more access to debt money that could intensify firm value. McCabe and Nowak (2008) reported that a ratio was required for independent directors on the board for efficient organisational management. Kumar and Sivaramakrishnan (2008) indicated a negative relationship between the participating independent directors and firm value, as opposed to the study findings. Hence, the research hypothesis on the link between board independence and firm value was rejected.

Besides, the connection between institutional ownership and firm value was insignificant and implied that institutional ownership could not influence firm value. Navissi and Naiker (2006) revealed an insignificant link between institutional ownership and firm value in line with the study results. Wei et al. (2005) showed a positive and significant association between institutional ownership and firm value. Thus, the research hypothesis on the positive association between institutional shareholdings and firm value was rejected.

The study results revealed that managerial ownership had a positive and insignificant relationship with firm value and indicated that managerial participation in ownership was not regarded as a motivational force to influence firm value. However, Kumar and Singh (2013) and Lee et al. (2008) indicated a positive and significant approach between managerial ownership and firm value. Therefore, the research hypothesis on a positive and significant relationship between managerial ownership and firm value was rejected. Additionally, firm size had a negative and significant relationship with firm value and signified that organisational growth tended to reduce firm value. Large firms might have less control over management and services and caused a decline in firm value (Myers, 2001). Although the study result corresponded to Cheng et al. (2010), the result contradicted Rajan and Zingales (1995). Hence, the hypothesis of a positive correlation between firm size and firm value was rejected.

On the other hand, ROA or profitability was found to be positive and significant with the profitability to adapt to the finance theory (Mayers, 1977). Nevertheless, the hypothesis on the relationship between profitability and firm value was accepted. Finally, it was confirmed that CEO duality had no significant relationship 
Tab. 5: Results of panel corrected standard errors

\begin{tabular}{l|c|c|c|c}
\multirow{2}{*}{ Variable } & \multicolumn{4}{|c}{ Panel corrected standard error (PCSE) } \\
\cline { 2 - 5 } & Coefficient & Std. error & Z-statistic & P-value \\
\hline Constant & 10.04536 & 2.855397 & 3.52 & 0.0000 \\
\hline BS & $0.3139443^{* *}$ & 0.1064284 & 2.95 & 0.003 \\
\hline BC & -0.8572218 & 0.87019 & -0.99 & 0.325 \\
\hline IO & -0.0840202 & 0.7500734 & -0.11 & 0.911 \\
\hline MNO & 0.2171515 & 1.161882 & 0.19 & 0.852 \\
\hline BI & 3.080712 & 2.114194 & 1.46 & 0.145 \\
\hline ROA & $-0.5076032^{* * *}$ & 0.1359868 & -3.73 & 0.000 \\
\hline Duality & $31.51971^{* * *}$ & 4.230150 & 7.45 & 0.000 \\
\hline R-squared & $-0.0530195^{* *}$ & 0.4433631 & -0.12 & 0.005 \\
\hline Wald statistic & & & 0.1715 & \\
\hline Prob(F-statistic) & & \multicolumn{3}{l}{} \\
\hline
\end{tabular}

Source: own

with firm value. Joint leadership through CEO duality could not significantly perform managerial functions to enhance firm value (Foster, 2004). Regardless, Abor and Biekpe (2007) indicated a positive and significant relationship between CEO duality and firm value. Therefore, more than $50 \%$ of predictors were found to be significant and indicated the efficient formation of the econometrics model.

Tab. 5 reports the estimates of results from PCSE-testing that showed the link between corporate governance and firm value. The result revealed a positive and significant board size effect at 0.1 coefficient and indicated a higher firm value with more efficient board size. For example, Musa et al. (2018) reported that board size (number of board members) linked to board authority effectiveness, company performance, and information asymmetry. A large board size consisted of many experts (in terms of knowledge and experience) in favour of the interests of a firm and could make the right decision to increase firm value.

According to the trade-off theory, a large board size influenced board decisions in borrowing more for the capital structure to obtain tax exemption and maximise firm value. Previous studies such as Carter et al. (2003) showed that a large board size enabled the board to make efficient decisions in enhancing firm value. However, contradictory results were supported by Gill et al. (2011). Therefore, the research hypothesis on a negative relationship between board size and firm value was rejected. Nonetheless, a negative and insignificant association between board composition and firm value was indicated in the study. As board composition pertained to member diversity involving qualification, experience, selection process, degree of autonomy, rationality, ethical values for meeting inputs that may improve corporate governance, and firm value, the insignificance could be based on the aforementioned facts.

It was also observed that board composition involved family and politically connected members who tended to impose board authority for personal interests. Previous studies such as Nguyen and Faff (2007) indicated a positive and significant connection between board composition and firm value. Diversity in board composition or structure resulted in higher board efficiency. Hermalin and Weisbach (1991) revealed a weak correlation between board composition and firm value. Hence, the research hypothesis on a negative and significant relationship between board composition and firm value was rejected.

Concerning institutional ownership, a negative and insignificant correlation between institutional ownership and firm value revealed that institutional ownerships involving the board 
reduced firm value. The negative impact on firm value indicated that institutional shareholders blocked shareholdings by influencing the organisational decisions beyond the interests of the firm. However, previous studies indicated a negative and significant relationship between institutional shareholdings and firm value (Wei et al., 2005). Wei et al. (2005) reflected a positive and significant correlation between institutional ownership and firm value. Thus, the research hypothesis on a positive and significant relationship between institutional ownership and firm value was rejected.

Regarding managerial ownership, the results indicated that managerial ownership had a positive and insignificant relationship with firm value. Stock purchase options in gaining managerial ownership were not considered a motivational force for managers in the study (Kumar \& Singh, 2013). On the contrary, managerial ownership was found to have a positive and significant relationship with firm value and provided a strategy to mitigate the agency problem (Kumar \& Singh, 2012). Therefore, the research hypothesis on the association between managerial ownership and firm value was rejected.

Additionally, board independence had a positive and insignificant correlation with the firm. The reason for the insignificance in board independence involved the board minority selected through political considerations who could not influence the board meeting dominated by the board chair and CEO. Nevertheless, previous studies showed a positive and significant relationship between board independence and firm value. The participating independent director on the board played a strong monitoring role in management (McCabe \& Nowak, 2008), whereas Bhagat and Black (2001) indicated a negative and significant relationship between board independence and firm value. Hence, the research hypothesis on a positive relationship between board independence and firm value was rejected.

The results indicated that firm size had a negative and significant effect on firm value, thus revealing that a firm with more diversity in products and services and challenges in controlling the managerial functions would incur a high cost and reduce firm value. Previous studies adopted the presumptions of this study (Myers, 2001). Additionally, Rajan and Zingales (1995) reported that company size was positively related to firm value. Hence, the hypothesis of a positive association between firm size and firm value was rejected. However, ROA or profitability had a positive and significant relationship with firm value. The finding was adapted to the finance theory such as the trade-off theory and predicted a positive relationship between profitability and firm value. Hence, the research hypothesis on a positive relationship between profitability and firm value was accepted.

The CEO duality showed an inverse association to firm value, indicating that firm value declined with the aggressive hold of power by the CEO through joint leadership. In the Bangladeshi context, having sole authority led to the exclusion of other board members in decisionmaking. Using the board chair, decisions were made in favour of the CEO's interests. It was observed that CEO duality usually occurred when family members and political persons held maximum shares. Following CEO duality, dual roles were established regardless of the minority interest in the corporation and considerably hampered the corporate governance system through familial and governmental connections beyond the rule of law. As such, previous research supported the study findings (Uwugbei, 2014). Consequently, the research hypothesis on a positive relationship between CEO duality and firm value was rejected.

\section{Concluding Remarks and Policy Implications}

For a developing country such as Bangladesh, corporate governance is the most discussable issue among regulators, academicians, and policymakers. The recent corporate governance index has fallen due to the lack of democracy and corruption in the government. Therefore, the paper examined the impact of corporate governance on firm value. However, the results indicated that board structure positively influenced firm value as a strong board structure could supervise the managers and communicate with stakeholders on excellent financial, capital, and raw material management to enhance firm value.

Previous studies equally adopted the empirical results of the study (Gill et al., 2011; Carter et al., 2003). However, some previous studies opposed the finding. For example, Gill et al. (2011) reported that board size 
had a negative relationship with firm value and argued that a large board size created complexities and conflicts that incurred agency and managerial costs, consequently reducing firm value. In contrast, a negative and insignificant relationship between board composition and firm value indicated that external directors could not effectively control the board and internal directors due to political affiliations in Bangladesh. No individual could exercise power over the political and family leaders currently linked to the Bangladeshi government (Hermalin \& Weisbach, 1991). Hence, it was indicated that institutional ownership had a negative and insignificant relationship with firm value in line with previous studies (Wei et al., 2005).

Also, board independence was regarded as a non-functional body in family-oriented and politically-affiliated firms. Independent directors were politically appointed by the current government with no liberty to play an active role as reviewed in previous studies (Bhagat \& Black, 2001). On the contrary, managerial ownership had a positive and insignificant association to firms, implying that managerial ownership did not motivate company operations if managers were not compensated based on status and investment (Kumar \& Singh, 2013). In the two control variables concerned (firm size and profitability), firm size had an inverse and significant relationship with firm value.

In contrast, probability had a positive and significant relationship with firm value. Nevertheless, the most significant result was CEO duality with an inverse and significant association to firm value. A firm led by CEO duality in family-oriented and politicallyaffiliated firms would decrease firm value. Politically-considered deeds in recent times, regardless of the free and fair management of the government, influenced corporate governance (Uddin et al., 2019). Implementing joint leadership through CEO duality would decrease firm value due to the advantageous position of using political and family-oriented power for corruption. The statement reflects the current practice in Bangladesh in line with previous study findings (Baliga et al., 1996).

Moreover, policy implications are required for strategic decisions. First, better legislations are necessary to improve the current corporate governance system by setting free and fair regulators. The current regulatory system is directed by the political consideration of the government for approval, registration, appointment, and as a monitoring system. In removing political affiliations from the regulatory system, the government requires professional directions to install a holistic regulatory body to improve the corporate governance system. Additionally, companies should be formed through dispersed shareholdings and the approval of companies free from political and family-oriented affiliations to ensure corporate governance. By enforcing company laws, firms can strictly comply with corporate governance rules and regulations internally in serving the mission, vision, and objectives and preventing personal or political gains.

Furthermore, independent directors should be increased to $30 \%$ of the total directors following developed countries like the USA to intervene in unethical issues on board meetings and provide valuable suggestions involving corporate governance. Besides, firms need board diversification with regards to qualification, knowledge, experience, rationality, moral values, sincerity, and decision-making power in supporting managers to follow corporate governance principles. Moreover, corporate governance acts should include a sufficient degree of freedom and power to professionally manage firms with corporate governance.

Despite the contribution of this paper, some limitations were identified for future research directions. Firstly, the study only included manufacturing companies which restricted the generalisation of results for policy directions. Therefore, future studies should include all types of listed companies in Bangladesh. Secondly, the study did not cover companies in the financial sector. Regardless, the corporate governance impact on the financial industry is considered indispensable in protecting the public interest. Hence, future studies should examine the corporate governance impact on financial and capital markets. Lastly, the study did not cover the roles of regulatory bodies in corporate governance quality involving listed companies, thus limiting the current study findings. Hence, future studies may be directed to the roles of regulatory bodies in corporate governance quality concerning Bangladeshi listed companies. 


\section{References}

Abor, J., \& Biekpe, N. (2007). Corporate governance, ownership structure and performance of SMEs in Ghana: Implications for financing opportunities. Corporate Governance International Journal of Business in Society, 7(3), 288-300. https://doi. org/10.1108/14720700710756562

Acharya, V. V., \& Bisin, A. (2009). Managerial hedging, equity ownership, and firm value. The RAND Journal of Economics, 40(1), 47-77. https://doi.org/10.1111/j.17562171.2008.00055.x

Adegbile, S. A. (2015). Corporate Governance Attributes and Capital Structure of Listed Firms in the Nigerian Food and Beverages Industry. International Journal of Public Administration and Management Research, 3(1), 48-56.

Alagathurai, A. (2013). Impact of Corporate Governance Practices on Firm Capital Structure and Profitability: A Study of Selected Hotels and Restaurant Companies in Sri Lanka. Research Journal of Finance and Accounting, 4(10), 115-126.

Alfi, S., \& Safarzadeh, M. H. (2016). Effect of Capital Structure and Liquidity on Firm Value. International Journal of Applied Business and Economic Research, 14(14), 10143-10153.

Baliga, B. R., Moyer, R. C., \& Rao, R. S. (1996). CEO Duality and Firm Performance: What's the fuss? Strategic Management Journal, 17(1), 41-53. Retrieved from https://www.jstor.org/stable/2486936

Beck, N., \& Katz, J. N. (1995). What to do (and not to do) with time-series cross-section data. American Political Science Review, 89(3), 634-647. https://doi.org/10.2307/2082979

Bhagat, S., \& Black, B. (2001). The Noncorrelation Between Board Independence and Long-Term Firm Performance. Journal of Corporation Law, 27(2), 231-274. Retrieved from https://heinonline.org/ $\mathrm{HOL} /$ LandingPage?handle=hein.journals/ jcorl27\&div=18\&id=\&page=

Brown, P., Beekes, W., \& Verhoeven, P. (2011). Corporate governance, accounting and finance: A review. Accounting and Finance, 51(1), 96-172. https://doi.org/10.1111/j.1467629X.2010.00385.x

Boyd, B. K. (1995). CEO duality and Firm Performance: A Contigency Model. Strategic Management Journal, 16(4), 301-312. https://doi.org/10.1002/smj.4250160404
Carter, D. A., Simkins, B. J., \& Simpson, W. G. (2003). Corporate Governance, Board Diversity, and Firm Value. Financial Review, 38(1), 33-53. https://doi.org/10.1111/15406288.00034

Céspedes, J., González, M., \& Molina, C. A. (2010). Ownership and capital structure in Latin America. Journal of Business Research, 63(3), 248-254. https://doi.org/10.1016/j. jbusres.2009.03.010

Cheng, Y. S., Liu, Y. P., \& Chien, C. Y. (2010). Capital Structure and Firm Value in China: A Panel Threshold Regression Analysis. African Journal of Business Management, 4(12), 2500-2507. Retrieved from https:// academicjournals.org/app/webroot/article/ article1380789599_Cheng\%20et\%20al.pdf

Claessens, S. (2006). Corporate governance and development. The World Bank Research Observer, 21(1), 91-122. https://doi. org/10.1093/wbro/lkj004

Cheng, S. J. (2008). Board size and the variability of corporate performance. Journal of Financial Economics, 87(1), 157-176. https://doi.org/10.1016/j.jfineco.2006.10.006

Combs, J. G., Ketchen Jr, D. J., Perryman, A. A., \& Donahue, M. S. (2007). The Moderating Effect of CEO Power on the Board Composition - Firm Performance Relationship. Journal of Management Studies, 44(8), 1299-1323. https://doi.org/10.1111/j.1467-6486.2007.00708.x

Diamond, D. W., \& Rajan, R. (2000). A Theory of Bank Capital. The Journal of Finance, 55(6), 2431-2465. https://doi. org/10.1111/0022-1082.00296

dos Santos Silva, E., dos Santos, J. F., \& Almeida, M. A. (2011). Conselho de Administração: uma análise da influência nos níveis de endividamento. Revista Brasileira de Gestão dos Negócios, 13(41), 440-453. https://doi.org/10.7819/rbgn.v13i41.835

Duchin, R., Matsusaka, J. G., \& Ozbas, O. (2010). When Are Outside Directors Effective? Journal of Financial Economics, 96(2), 195-214. https://doi.org/10.1016/j.jfineco.2009.12.004

Erickson, M., \& Wang, S. W. (1999). Earnings Management by Acquiring Firms in Stock for Stock Mergers. Journal of Accounting and Economics, 27(2), 149-176. https://doi. org/10.1016/S0165-4101(99)00008-7

Ehikioya, B. I. (2009). Corporate Governance Structure and Firm Performance in Developing Economies: Evidence From Nigeria. Corporate Governance, 9(3), 231-243. 
https://doi.org/10.1108/14720700910964307

Fosberg, R. H. (2004). Agency Problems and Debt Financing: Leadership Structure Effects, Corporate Governance. International Journal of Business in Society, 4(1), 31-38. https://doi.org/10.1108/14720700410521943

Fumani, M. A., \& Moghadam, A. (2015). The Effect of Capital Structure on Firm Value: The Rate of Return on Equity and Earnings per Share of Listed Companies in Tehran Stock Exchange. Research Journal of Finance and Accounting, 6(15), 50-57.

Gill, A., Biger, N., \& Mathur, N. A. (2010). The Relationship between Working Capital Management and Profitability: Evidence from the United States. Business and Economic Journal, 10, 51-64. Retrieved from https:// pdfs.semanticscholar.org/eae3/6d68670 d790370f13a1c144f236665b04ac2.pdf

Gill, A., \& Mathur, N. (2011). Board Size, CEO Duality, and The Value of Canadian Manufacturing Firms. Journal of Applied Finance \& Banking, 1(3), 1-13.

Gill, M. S., Vijay, T. S., \& Jha, S. (2009). Corporate Governance Mechanisms and Firm Performance: A Survey of Literature. The Icfai University Journal of Corporate Governance, 8(1), 7-21. Retrieved from https://search.proquest.com/openview/a5e 807 c44acdd6f1773ab6cad2b338fe/1?pqorigsite $=$ gscholar $\& \mathrm{cbl}=54446$

Haque, F., Arun, T. G., \& Kirkpatrick, C. (2011). Corporate Governance and Capital Structure in 646 Developing Countries: A Case study of Bangladesh. Applied Economics, 43(6), 673-681. https://doi.org/10.1080/00036840802599909

Hausman, J. A. (1978). Specification Tests in Econometrics. The Journal of Econometrics, 46(6), 1251-1271. https://doi. org/10.2307/1913827

Hermalin, B. E., \& Weisbach, M. S. (1991). The Effects of Board Composition and Direct Incentives on Firm Performance. Journal of Financial Management, 20(4), 101-112. https://doi.org/10.2307/3665716

Joh, S. W. (2003). Corporate Governance and Firm Profitability: Evidence from Korea before the Economic Crisis. Journal of Financial Economics, 68(2), 287-322. https://doi. org/10.1016/S0304-405X(03)00068-0

Kumar, P., \& Sivaramakrishnan, K. (2008). Who monitors the monitor? The Effect of Board Independence on Executive Compensation and Firm Value. The Review of Financial Studies,
21(3), 1371-1401. https://doi.org/10.1093/rfs/ hhn010

Kumar, N., \& Singh, J. P. (2013). Effect of Board Size and Promoter Ownership on firm value: Some Empirical Findings From India. Corporate Governance, 13(1), 88-98. https://doi.org/10.1108/14720701311302431

Kumar, N., \& Singh, J. P. (2012). Outside Directors, Corporate Governance and Firm Performance: Empirical Evidence from India. Asian Journal of Finance \& Accounting, 4(2), 39-54. http://dx.doi.org/10.5296/ajfa.v4i2.1737

Kyereboah-Coleman, A., \& Biekpe, N. (2006). Do Boards and CEOs Matter for Bank Performance? A Comparative Analysis of Banks in Ghana. Corporate Ownership and Control, 4(1), 119-126. https://doi.org/10.22495/ cocv4i1p10

La Porta, R., Lopez-de-Silanes, F., \& Shleifer, A. (2006). What works in securities laws? Journal of Finance, 61(1), 1-32. https://doi.org/10.1111/j.1540-6261.2006.00828.x

Lee, K. W., Lev, B., \& Yeo, G. H. H. (2008). Executive Pay Dispersion, Corporate Governance, and Firm Performance. Review of Quantitative Finance and Accounting, 30(3), 315338. https://doi.org/10.1007/s11156-007-0053-8

Lefort, F., \& Urzúa, F. (2008). Board independence, firm performance and ownership concentration: Evidence from Chile. Journal of Business Research, 61(6), 615-622. https://doi.org/10.1016/j.jbusres.2007.06.036

Mitton, T. (2002). A cross-firm analysis of the impact of corporate governance on the East Asian financial crisis. Journal of Financial Economics, 64(2), 215-241. https://doi. org/10.1016/S0304-405X(02)00076-4

Myers, S. C., \& Majluf, N. S. (1984). Corporate financing and investment decisions when firms have information that investors do not have. Journal of Financial Economics, 13(2), 187-221. https://doi.org/10.1016/0304405X(84)90023-0

Myers, S. C. (2001). Capital structure. Journal of Economic Perspective, 15(2), 81-102. Retrieved from https://www.jstor.org/ stable/2696593

Musa, H., Musová, Z., \& Debnárová, L. (2018). Importance of Corporate Governance in Socially Responsible Behaviour of Enterprises. In L. Mura (Ed.), Entreprenership - Development Tendencies and Empirical Approach (pp. 247-265). London: IntechOpen. https://doi.org/10.5772/intechopen.70536 
Musa, H., Rech, F., \& Musová, Z. (2019). The Role of Corporate Governance in Debt and Dividend Polices: Case of Slovakia. Investment Management and Financial Innovations, 16(2), 206-217. http://dx.doi.org/10.21511/ imfi.16(2).2019.18

McCabe, M., \& Nowak, M. (2008). The independent director on the board of company directors. Managerial Auditing Journal, 23(6), 545-566. https://doi. org/10.1108/02686900810882101

Nguyen, H., \& Faff, R. (2007). Impact of Board Size and Board Diversity on Firm Value: Australian Evidence. Corporate Ownership \& Control, 4(2), 24-32. http://dx.doi.org/10.22495/ cocv4i2p2

Navissi, F., \& Naiker, V. (2006). Institutional Ownership and Corporate Value. Managerial Finance, 32(3), 247-256. https://doi. org/10.1108/03074350610646753

Peng, M. W., Zhang, S., \& Li, X. (2007). CEO Duality and Firm Performance During China's Institutional Transitions. Management and Organization Review, 3(2), 205-225. https:// doi.org/10.1111/j.1740-8784.2007.00069.x

Pucheta-Martínez, M. C. (2015). The role of the Board of Directors in creation of value for the company. Revista de Contabilidad Spanish Accounting Journal, 18(2), 148-161. https://doi.org/10.1016/j.rcsar.2014.05.004

Rashid, A., De Zoysa, A., Lodh, S., \& Rudkin, K. (2010). Board Composition and Firm Performance: Evidence from Bangladesh. Australasian Accounting, Business and Finance Journal, 4(1), 76-95. Retrieved from https:// ro.uow.edu.au/aabfj/vol4/iss 1/5/

Rashid, K., \& Islam, S. M. N. (2013). Corporate governance, complementarities and the value of a firm in an emerging market: the effect of market imperfections. Corporate Governance, 13(1), 70-87. https://doi. org/10.1108/14720701311302422

Ruiz-Mallorquí, M. V., \& Santana-Martín, D. J. (2011). Dominant Institutional Owners and Firm Value. Journal of Banking \& Finance, 35(1), 118-129. https://doi.org/10.1016/j. jbankfin.2010.07.020

Rouf, D. (2011). The Relationship between Corporate Governance and Value of the Firm in Developing Countries: Evidence from Bangladesh. The International Journal of Applied Economics and Finance, 5(3), 237-244. Retrieved from https://ssrn.com/ abstract $=2576591$
Rajan, R. G., \& Zingales, L. (1995). What do we know about Capital structure? Some Evidence from International Data. The Journal of Finance, 50(5), 1421-1460. https://doi. org/10.1111/j.1540-6261.1995.tb05184.x

Reed, W. R., \& Ye, H. (2011). Which panel data estimator should I use? Applied Economics, 43(8), 985-1000. https://doi. org/10.1080/00036840802600087

Robertson, D., \& Symons, J. (2000). Factor Residuals in SUR Regressions: Estimating Panel Allowing for Cross Sectional Correlations (Discussion Paper dp0473). London: Centre for Economic Performance.

Titman, S., \& Wessel, R. (1988). The Determination of Capital Structure Choice. The Journal of Finance, 43(1), 1-19. https://doi. org/10.1111/j.1540-6261.1988.tb02585.x

Torres-Reyna, O. (2007). Panel Data Analysis Fixed and Random Effects Using Stata (V. 4.2) (Web Presentation). Data Statistical Services, Princeton University, Princeton.

Uddin, M. N., Khan, M. S. U., \& Hosen, M. (2019). Does Corporate Governance Influence Leverage Structure in Bangladesh? International Journal of Financial Studies, 7(3), 50. https://doi.org/10.3390/ijfs7030050

Uwuigbe, U. (2014). Corporate Governance and Capital Structure: Evidence from Listed Firms in Nigeria Stock Exchange. The Journal of Accounting and Management, 4(1), 5-14.

Weekes-Marshall, D. (2014). Corporate Governance Disclosure Practices: Evidence from Barbados. Social and Economic Studies, 63(3/4), 307-341. Retrieved from https://www. jstor.org/stable/44732895

Wei, Z., Xie, F., \& Zhang, S. (2005). Ownership Structure and Firm Value in China's Privatized Firms: 1991-2001. Journal of Financial and Quantitative Analysis, 40(1), 87-108. https://doi.org/10.1017/ S0022109000001757

Wooi, H. C., \& Ming, T. C. (2009). Directors' Pay-Performance: A Study on Malaysian Government Linked Companies (CenPRIS Working Paper No. 110/09). Penang: Universiti Sains Malaysia.

Wintoki, M. B., Linck J. S., \& Netter, J. M. (2012). Endogeneity and the dynamics of internal corporate governance. Journal of Financial Economics, 105(3), 581-606. https:// doi.org/10.1016/j.jfineco.2012.03.005

Wen, Y., Rwegasira, K., \& Bilderbeek, J. (2002). Corporate Governance and 


\section{Business Administration and Management}

Capital Structure Decisions of the Chinese Listed Firms. Corporate Governance: An International Review, 10(2), 75-83. https://doi. org/10.1111/1467-8683.00271
Yan Lam, T., \& Kam Lee, S. (2008). CEO Duality and Firm Performance: Evidence from Hong Kong. Corporate Governance: The International Journal of Business in Society, 8(3), 299-316. https://doi. org/10.1108/14720700810879187 